\title{
FOOD RESOURCES SUSTAINING THE FISH FAUNA IN A SECTION OF THE UPPER SÃO FRANCISCO RIVER IN TRÊS MARIAS, MG, BRAZIL
}

\author{
ALVIM, M. C. C. ${ }^{1}$ and PERET, A. C. ${ }^{2}$ \\ ${ }^{1}$ Programa de Pós-graduação em Ecologia e Recursos Naturais, Universidade Federal de São Carlos, \\ Via Washington Luís, km 235, C.P. 676, CEP 13565-905, São Carlos, SP, Brazil \\ ${ }^{2}$ Departamento de Hidrobiologia, Universidade Federal de São Carlos, Via Washington Luís, km 234, \\ C.P. 676, CEP 13565-905, São Carlos, SP, Brazil \\ Correspondence to: Márcio C. C. Alvim, Programa de Pós-graduação em Ecologia e Recursos Naturais, \\ Universidade Federal de São Carlos, Via Washington Luís, km 235, C.P. 676, \\ CEP 13565-905, São Carlos, SP, Brazil, e-mail: marcio.bhz@terra.com.br \\ Received November 5, 2002 - Accepted February 17, 2003 - Distributed May 31, 2004
}

(With 4 figures)

\begin{abstract}
With the purpose of determining the principal food resources responsible for maintaining the fishery yield in a section of the São Francisco River, 6 sampling of the fish fauna were made downstream from the Três Marias Dam, from September 1996 to July 1997. A total of 1,127 individuals of 35 species were captured, using gillnets with mesh sizes varying from 3 to $16 \mathrm{~cm}$. The stomach contents of 33 species were examined in order to determine their diets. Five trophic guilds were established, in the following order of importance: ilyophagous, herbivorous, piscivorous, terrestrial invertebrates feeders, and aquatic invertebrates feeders. The resources sustaining the fish fauna were mainly of allochthonous origin. The ichthyonenosis appears to be mainly dependent on the detritus chain. The ciliary forest and seasonal flooding pulses are the main suppliers of food for the fish fauna.
\end{abstract}

Key words: trophic ecology of fishes, feeding habits, resources partitioning, São Francisco River.

\section{RESUMO}

\section{Recursos alimentares que sustentam a ictiofauna em um trecho do alto rio São Francisco, município de Três Marias, MG, Brasil}

Com o objetivo de determinar os principais recursos alimentares responsáveis pela manutenção da produtividade pesqueira do rio São Francisco, foram realizadas 6 coletas da ictiofauna a jusante da barragem de Três Marias, no período de setembro de 1996 a julho de 1997. Um total de 1.127 indivíduos pertencentes a 35 espécies foram capturados com redes de malhas variando de 3 a $16 \mathrm{~cm}$. Os conteúdos estomacais de 33 espécies foram analisados para determinar suas dietas. Estabeleceramse cinco grupos tróficos principais que, em ordem de importância, foram: Iliófagos, Herbívoros, Piscívoros, Invertívoros Terrestres e Invertívoros Aquáticos. Os recursos naturais que sustentam a ictiofauna são principalmente de origem alóctone. A ictiocenose parece ser dependente principalmente da cadeia de detritos. A vegetação marginal e as variações do nível da água são os principais fornecedores de recursos alimentares para a ictiocenose estudada.

Palavras-chave: ecologia trófica de peixes, hábitos alimentares, partilha de recursos, rio São Francisco.

\section{INTRODUCTION}

South American fresh water fish fauna is the richest in species when compared to that of any other zoogeographic region (Lowe-McConnell, 1984). Within this context, Brazil has the most diversified fish fauna on the planet (Godinho, 1993). Though exuberant, this taxonomic group has been seriously 
affected by several human activities, particularly the pollution of water bodies (e.g. disposal of industrial and domestic effluents), inadequate use of the soil (e.g. mining, sand extraction, removal of ciliary forest, cattle breeding, and crop growing), damming of the rivers for electric power generation, and overfishing (Goulding, 1980; Tundisi, 1986; Esteves \& Barbosa, 1986; Ribeiro \& Miranda, 1990; Godinho, 1993; Agostinho et al., 1995). These activities tend to expand and, in a disastrously synergic effect, may cause irreversible damage to fish stocks (Chagas, 1994).

The construction of the Três Marias Hydroelectric Power Plant in 1960 has caused important changes in the fish taxocenosis in the São Francisco River (Godinho, 1993) and, because this river concentrates the largest number of fishermen in the State of Minas Gerais (Miranda et al., 1988), it has also affected the fishing sector. Downstream from the Três Marias Reservoir, there has been a noticeable reduction in the fish population as a result of decreased productivity of the waters and control of river discharge, preventing the flooding of many oxbow lakes that used to function as natural growth sites of fingerlings (Ribeiro \& Miranda, 1990; Godinho, 1993).

With three large hydroelectric power plants slated for construction in Minas Gerais, downstream from Três Marias (Eletrobrás, 1987), it is plausible to assume that the taxocenosis of the fishes, as well as professional fishing, will suffer heavy impact. Therefore, studies aimed at determining the natural resources that are directly responsible for maintenance of the fishery yield are of great environmental, economic, and social importance.

This research describes the food composition of the species studied and their trophic classification, establishes food guilds, quantifies the importance of each food resource for maintaining fish fauna, and discusses the origin of each in order to determine which natural resources and processes are responsible for fishery yield in the studied area and so must be preserved on a priority basis.

\section{MATERIAL AND METHODS}

The biological material was obtained in a section of the upper São Francisco River located between the confluence of the Abaeté River and the Janeiro River, near Cilga Island, about $35 \mathrm{~km}$ downstream from, and under the direct influence of, the Três
Marias Dam. Even though, this is one of the most preserved sections of the São Francisco River in Minas Gerais, its ciliary forest has become increasingly reduced, due to regional cattle breeding and crop growing, and also to sports fishing.

Six collections were made bi-monthly from September 1996 to July 1997. The same set of gillnets, with an identical proportion of mesh sizes varying from 3 to $16 \mathrm{~cm}$ between opposed knots, was used in all collections. Gillnets were placed late in the afternoon and removed the following morning. The fishes were identified according to Britski et al. (1988), tagged, and then fixed in 10\% formalin solution. The standard length and weight of the specimens were taken in the laboratory. The food items found in the stomach of the specimens were identified to the lowest possible taxonomic level and weighed separately. Prey identification was made under a stereoscopic or an optical microscope, according to the size of items ingested. The frequency of occurrence and gravimetric participation of each food item were calculated according to Hyslop (1980). The food composition and trophic classification of the species were determined based on the importance of the food items in the diets of their respective consumers, as established by the alimentary index (IAi) of Kawakami \& Vazzoler (1980), with modifications. Trophic guilds were established through cluster analysis. The biomass and richness of each trophic guild were determined, as well as the importance of each food resource in the maintenance of the fish fauna studied, proportionately to the biomass of each species.

\section{RESULTS}

A total of 1,127 individuals belonging to 35 species, 25 genera, 10 families, and 3 orders (Table 1) were captured.

The stomach contents of 547 individuals were examined. The food composition of the 33 species studied is shown in Table 2. For standardization and better visualization of the results, the various food items were grouped into eight categories, as follows: (1) fish: whole fishes or chunks of fish flesh, as well as scales, fins, or skeleton parts; (2) vegetal: fresh or decomposing leaves, flowers, fruits, and seeds; (3) aquatic invertebrates: insects in immature stages, adult insects, macrocrustaceans, Acaridae, Oligochaeta, and mollusks; (4) terrestrial invertebrates: insects in immature stages, adult insects, and spiders; (5) zooplankton: Cladocera, Copepoda, and Ostracoda; 
(6) algae: filamentous algae; (7) sediment: sediments of varying grain sizes and with different contents of algae and/or organic matter; (8) amphibian: Hyla sp.

The species studied were grouped according to the predominance of food items in their diets into five main trophic guilds as follows: (1) piscivorous: fish; (2) herbivorous: plants and algae; (3) aquatic invertebrates feeders: aquatic invertebrates; (4) terrestrial invertebrates feeders: terrestrial invertebrates; (5) ilyophagous: sediments. Mixed classifications, using two categories, were also made. The term "generalist invertebrates feeders" was used to describe species that feed on both aquatic and terrestrial invertebrates.

The grouping of the species according to diet similarity is shown in Fig. 1. The biomass and richness of the species captured in each main trophic group and in the mixed groups are illustrated in Figs. 2 and 3, respectively. Fig. 4 shows the extrapolation of the diet of the individuals studied to the entire taxocenosis, proportionately to the biomass of each species captured, showing the importance of each food resource in maintaining the studied fish fauna.

\section{DISCUSSION}

In spite of their complexity, food chains in tropical waters are usually supported by a limited number of sources, since long food chains require large amounts of energy. The high productivity in such environments may be associated with the fact that several fish species consume foods at lower trophic levels, which otherwise would be accessible to the fish fauna only by means of invertebrates (Araújo-Lima et al., 1995).

In South American river basins, the dominance of groups that feed on sediments suggests that these are a valuable and abundant resource (Bowen, 1984; Fugi, 1993; Gerking, 1994). Bonetto (1970) found that Prochilodus platensis answers for $60 \%$ of the total fish biomass in the Paraná River. Sato et al. (1987), working in oxbow lakes of the São Francisco River upstream from the Três Marias Dam, reported that over $41 \%$ of the total fish biomass was represented by the families Prochilodontidae and Curimatidae. Agostinho et al. (1989) observed that two ilyophagous species, Prochilodus scrofa and Rhinelepis aspera, represented 54\% of the total biomass captured by professional fishermen in the
Itaipu Reservoir. Braga (1990) found that ilyophagous species accounted for most of the fish biomass in a section of the Tocantins River, upstream from the Tucuruí Reservoir. Meschiatti (1995) found that sediments were the most import food item for all fish species in an oxbow lake of the Mogi-Guaçu River. In this study, the species considered as ilyophagous (C. elegans, C. lepidura, Hypostomus sp. 1, Hypostomus sp. 2, P. affinis, and P. margravii) represented $12.3 \%$ of the individuals and $37.2 \%$ of the fish biomass captured. These species constituted the largest trophic guild, thus evidencing the importance of sediments in maintaining the fish fauna. Although not exclusively ilyophagous, $B$. westermanni $(2.5 \%$ of the individuals and $0.6 \%$ of the captured fish biomass) has a diet most of which is based on sediment ingestion.

The main route of energy flow and organic matter cycling in large South American river basins is the detritus chain (Bowen, 1984). For the most part, organic detritus arises from seasonal flooding of the ciliary forest and floodplain, and is produced by the deposition and biodegradation of vegetal and animal matter on the soil, by bacteria and fungi decomposers, (Begon et al., 1990; Araújo-Lima et al., 1995). The available nutrients improve the algae populations and those, in turn, appear to be the main source of energy for the fish that feed on sediments (Araújo-Lima et al., 1986). Thus, the presence of the ciliary forest as well as seasonal flooding pulses are essential for the production and transport of this food resource to the fishes (Agostinho \& Zalewski, 1995; Gomes \& Agostinho, 1997). Almeida et al. (1993) and Resende et al. (1995) demonstrated that, during the high-water period, the feeding activity of $P$. lineatus is most intense and sediments have the largest content of organic matter. Fugi (1993) and Gomes \& Agostinho (1997) found that P. scrofa specimens in the Paraná River were in a better nutritional condition during high-water period. The water-level regularization promoted by the Três Marias Dam and ciliary forest removal should reduce the production and transport of sediments rich in organic matter. These anthrophic impacts cause changes in the hydrology and environmental complexity of the river, modifying the local aquatic biota and fishing potential (Agostinho \& Zalewski, 1995). The construction of new hydroelectric power plants downstream from the Três Marias Dam will represent added damage to the fish fauna. 
TABLE 1

List of taxons captured, with respective popular designations.

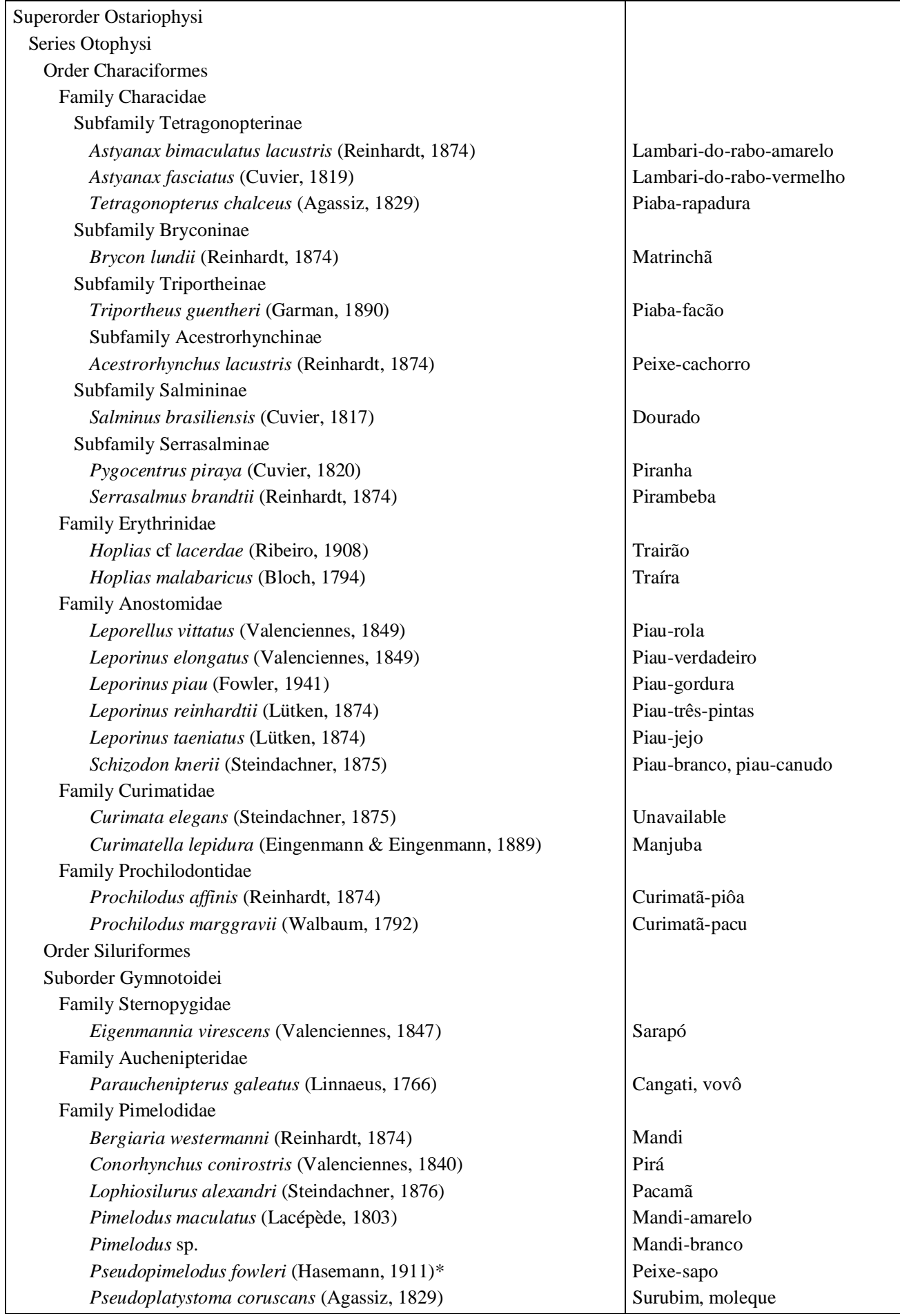


TABLE 1 (Continued).

Family Loricariidae

Hypostomus francisci (Lütken, 1873)*

Hypostomus sp. 1

Hypostomus sp. 2

Superorder Acanthopterygii

Series Percomorpha

Order Perciformes

Suborder Percoidei

Family Sciaenidae

Pachyurus francisci (Cuvier, 1830)

Pachyurus squamipinnis (Agassiz, 1829)

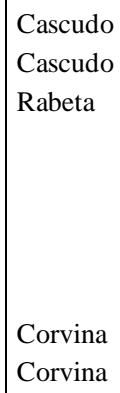

Source: Britski et al. (1988).

*The specimens of $P$. fowleri and $H$. francisci (only one of each) captured were kept alive for reproduction studies at the Três Marias Hydrobiology and Pisciculture Station (CEMIG/CODEVASF)

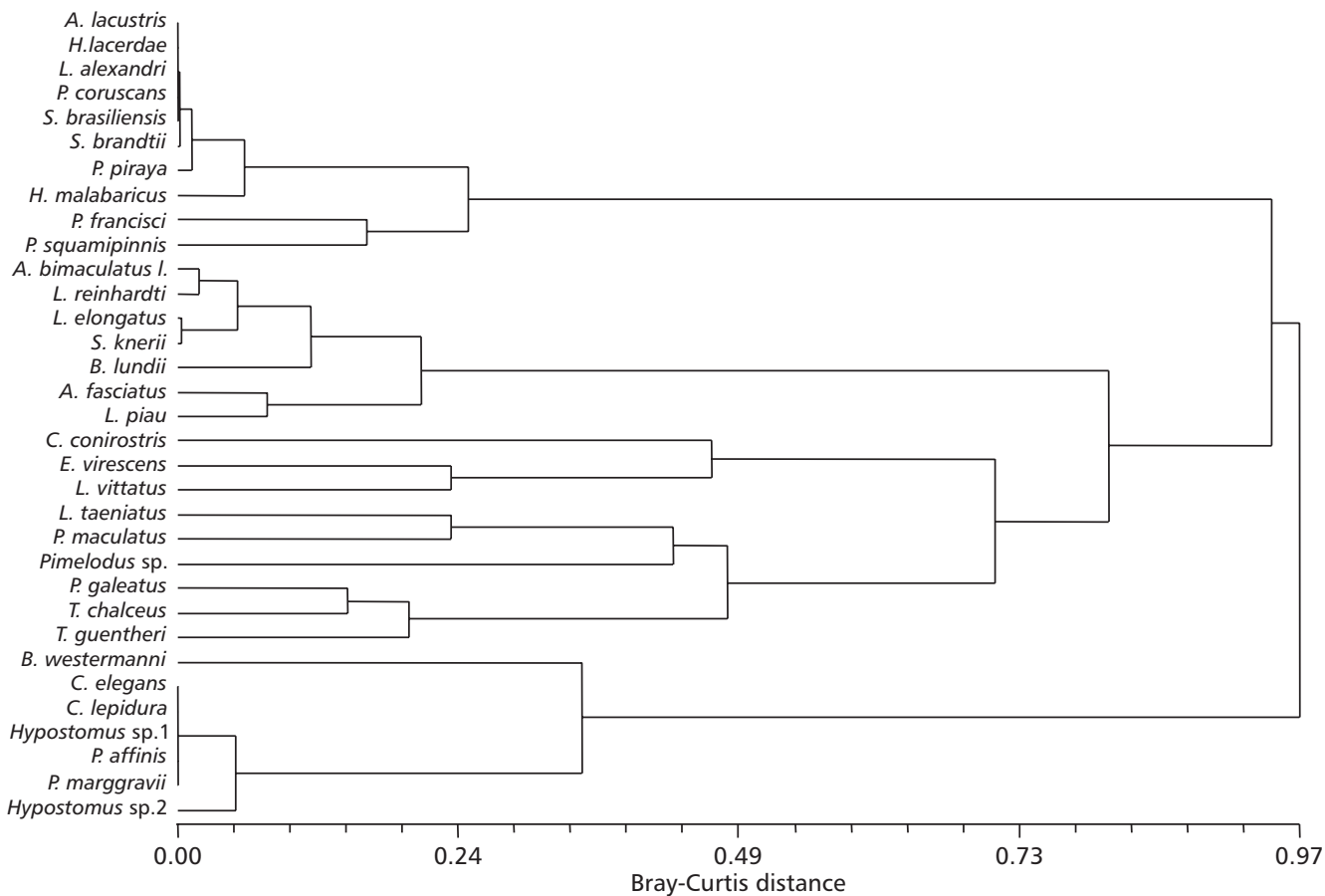

Fig. 1 - Cluster analysis dendogram with Bray-Curtis distance and UPGMA method $(r=0.96195)$.

According to Goulding (1980), the floodplains in South America have been so deeply changed by the various human activities that it is currently difficult to determine the degree of interaction between fishes and forests. We do know, however, that in seasonally flooded rivers the trophic chains have been dependent on vegetal matter of allochthonous origin (Goulding,
1980; Agostinho et al., 1995; Agostinho \& Zalewski, 1995). In the São Francisco River, in which the extent and duration of floods are smaller, the importance of riparian vegetation in directing maintaining the fish fauna has not yet been demonstrated. In this study, however, the species classified as herbivorous (Astyanax bimaculatus lacustris, Brycon lundii, 
Leporinus elongatus, Leporinus reinhardti, and Schizodon knerii) represented $32 \%$ of all individuals, $26.5 \%$ of the ichthyomass, and constituted the second largest trophic guild. In addition to those listed, Astyanax fasciatus and Leporinus piau (10.2\% of the individuals and $1.3 \%$ of the ichthyomass) were found to feed mostly on vegetal items. Meschiatti (1995) reported that plants and algae represented the second most important food item ingested by the entire fish taxocenosis in an oxbow lake of the Mogi-Guaçu River. According to Araújo-Lima et al. (1995), most of the species that feed on fruits and seeds also ingest other food items, suggesting an adaptive behavior that enables them to overcome the seasonal availability of such resources.

Zavala-Camin (1996) considers as herbivorous the species that select a living vegetal food. In the present work, also considered as herbivorous were the fish species that feed on leaves, fruits, seeds, and flowers that fall directly into the water, or on its margins, and are subsequently transported, in some degree of decomposition, to the river. This seems to be the most common situation for most of the herbivorous species in the studied section of the São Francisco River.

Usually, one expects to find only a small number of piscivorous fish species, since these occupy the top of the trophic hierarchy. However, some environments often show a surprising richness and abundance of biomass of this trophic guild (Sato et al., 1987; Araújo-Lima et al., 1995; Resende et al., 1996; Pompeu, 1997; Luiz et al., 1998). As a consequence, the piscivorous species probably play a fundamental role in the structuring of these communities (Gerking, 1994). Other environments, are not so propitious for piscivorous species, possibly because of the short or inconstant supply of preys
(Braga, 1990; Arcifa \& Meschiatti, 1993; Uieda et al., 1997; Luiz et al., 1998). Vannote et al. (1980) consider that piscivorous species should be common in intermediate-size rivers, in which the community's rate of consumption is high. In this study, the species that were considered as piscivorous (Acestrorhynchus lacustris, Hoplias cf lacerdae, Hoplias malabaricus, Lophiosilurus alexandri, Pachyurus francisci, Pygocentrus piraya, Pseudoplatystoma coruscans, Salminus brasiliensis, and Serrasalmus brandtii) represented $19.4 \%$ of all individuals and $19.9 \%$ of the ichthyomass of the entire taxocenosis, constituting the third largest trophic guild. In addition to these, Pachyurus squamipinnis (1.3\% of the individuals and $2.4 \%$ of the ichthyomass) had a diet mostly composed of fishes.

In studies on fish diets, terrestrial invertebrates are commonly considered allochthonous and aquatic invertebrates, autochthonous items. However, insects in immature stages, the main aquatic invertebrates consumed, are also dependent on terrestrial resources and, therefore, have a mixed origin. In either case, food resources are dependent on the ciliary forest.

It can thus be concluded that the natural resources responsible for maintaining productivity in the environment studied were predominantly of allochthonous origin. The ichthyocenosis appears to be mainly dependent on the detritus chain. The ciliary forest and seasonal flooding pulses are the main suppliers of food for the fish fauna.

This being a pioneer study on the trophic relationships of the fish fauna in the Upper São Francisco River channel, our concern was to determine the diet of the largest possible number of species, even if our findings are only partially conclusive, due to the limited number of specimens obtained for some species.

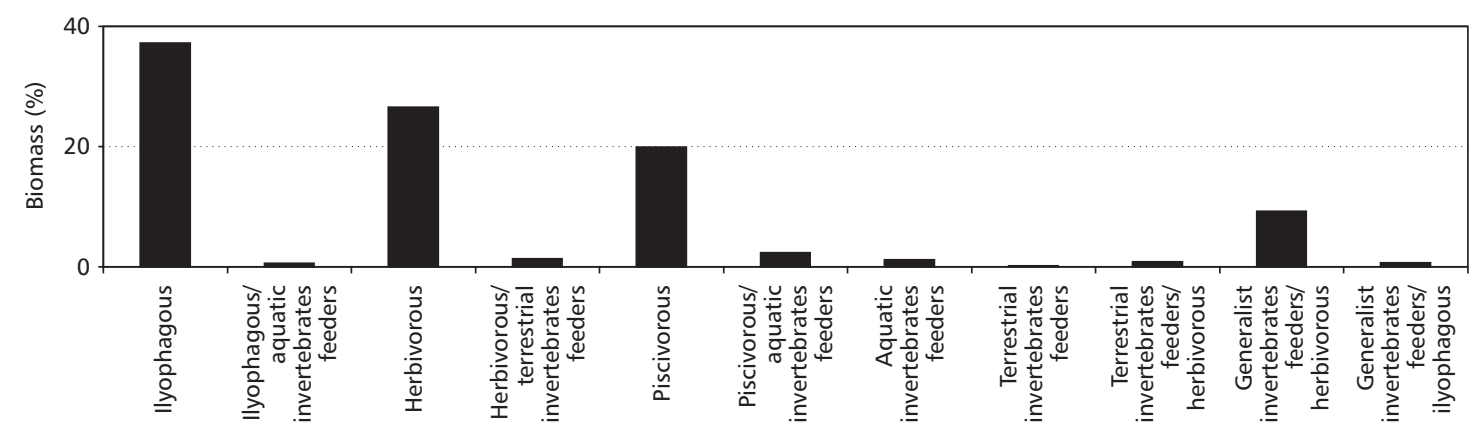

Fig. 2 - Biomass of each trophic guild. 


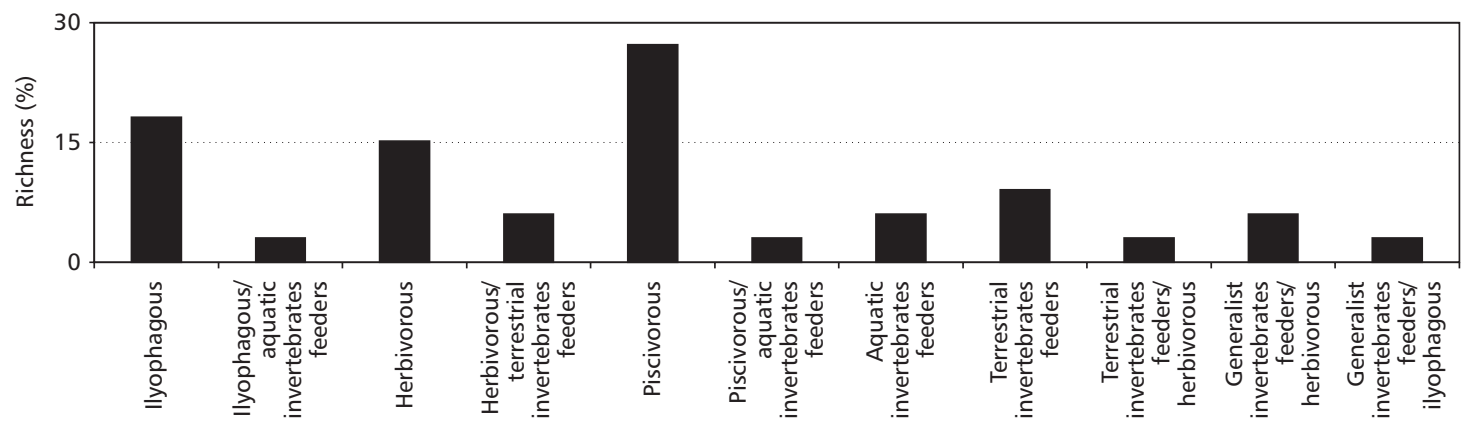

Fig. 3 - Richness of each trophic guild.

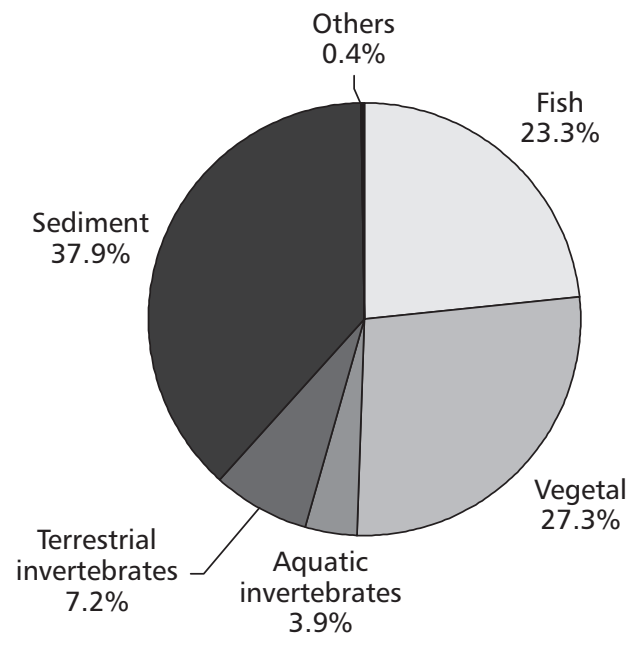

Fig. 4 - Relative importance of food resources for the ichthyocenosis studied.

Even so, our results represent an alert, indicating that conservation of the fish fauna and, consequently, of fishery, with all the related social and economic implications, depends on preservation of the ciliary forest and maintenance of the seasonal flooding pulses. For this reason, fish fauna conservation is incompatible with the various anthrophic interventions in the environment, particularly the construction of new hydroelectric power plants.

Acknowledgments - We thank the Três Marias Hydrobiology and Fishculture Station (CEMIG/CODEVASF), in particular Dr. Yoshimi Sato, and also the biologists Mário O. T. Miranda and Maria Beatriz Boschi of the Fisheries Department of IBAMA, MG, for their logistic support in fish collections. We are also thankful to professors José Roberto Verani and Izabel de Fátima Andrian for examining the dissertation in which this work originated, the biologist Alexandre K. Oliveira for his assistance in laboratory works and in checking the data, and the National Research Council (CNPq) for the grant of a scholarship.

\section{REFERENCES}

AGOSTINHO, A. A., BORGUETTI, J. R., DOMANICZKY, G. M., NOGUEIRA, S. V. G. \& OKADA, K., 1989, Produção pesqueira e situação da pesca no reservatório de Itaipu. In: Seminário Nacional de Grandes Barragens, 18, Foz do Iguaçu. Anais... Itaipu Binacional, Foz do Iguaçu.

AgOstinho, A. A., VAZZOLER, A. E. A. M. \& THOMAZ, S. M., 1995, The high river Paraná basin: Limnological and ichthyological aspects, pp. 59-104. In: J. G. Tundisi, C. E. M. Bicudo \& T. Matsumura-Tundisi (eds.), Limnology in Brazil. ABC/SBL, Rio de Janeiro.

AGOSTINHO, A. A. \& ZALEWSKI, M., 1995, The dependence of fish community structure and dynamics on floodplain and riparian ecotone zone in in Parana River, Brazil. Hydrobiologia, 303: 141-148.

ALMEIDA, V. L. L., RESENDE, E. K., LIMA, M. S. \& FERREIRA, C. J. A., 1993, Dieta e atividade alimentar de Prochilodus lineatus (Characiformes, Prochilodontidae) no Pantanal do Miranda-Aquidauana, Mato Grosso do Sul, Brasil. Unimar, 15(suplemento): 125-141. 
ARAÚJO-LIMA, C. A. R. M., AGOSTINHO, A. A. \& FABRÉ, N. N., 1995, Trophic aspects of fish communities in Brazilian rivers and reservoirs, pp. 105-136. In: J. G. Tundisi, C. E. M. Bicudo \& T. Matsumura-Tundisi (eds.), Limnology in Brazil. ABC/SBL, Rio de Janeiro.

ARAÚJO-LIMA, C. A. R. M., FORSBERG, R. V. \& MARTINELLI, L., 1986, Energy sources for detritivorous fishes in the Amazon. Science, 234: 1256-1258.

ARCIFA, M. S. \& MESCHIATTI, A. J., 1993, Distribution and feeding ecology of fishes in a Brazilian reservoir: Lake Monte Alegre. Interciencia, 18(6): 302-313.

BEGON, M., HARPER, J. L. \& TOWNSEND, C. R., 1990, Ecology: Individuals, populations and communities. Black Well Scientific Publications, Cambridge, Massachusetts, 943p.

BONETTO, A. A., 1970, Principal limnological features of northeastern Argentina. Soc. Arg. Bot., 11 (suplemento): 185209.

BOWEN, S. H., 1984, Detritivory in neotropical fish communities. In: T. M. Zaret (ed.), Evolutionary Ecology of Neotropical freshwater fishes. Dr. W. Junk, The Netherlands, 173p.

BRAGA, F. M. S., 1990, Aspectos da reprodução e alimentação de peixes comuns em um trecho do rio Tocantins entre Imperatriz e Estreito, estados do Maranhão e Tocantins, Brasil. Rev. Brasil. Biol., 50(3): 547-558.

BRITSKI, H. A., SATO, Y. \& ROSA, A. B. S., 1988, Manual de identificação de peixes da região de Três Marias. $3^{\mathrm{a}} \mathrm{ed}$. CODEVASF, Brasília, 115p.

CHAGAS, A. L. G. A., 1994, Pesca de águas interiores, pp. 14-23. In: Seminário sobre fauna aquática e o setor elétrico brasileiro, reuniões temáticas preparatórias: Caderno 3 Conservação. ELETROBRÁS, Rio de Janeiro.

ELETROBRÁS, 1987, Plano Nacional de Energia Elétrica 1987/2010. Plano 2010 - Relatório Executivo. ELETROBRÁS, Rio de Janeiro, 87p.

ESTEVES, F. A. \& BARBOSA, F. A. R., 1986, Eutrofização artificial - A doença dos lagos. Ciência Hoje, 5(27): 56-61.

FUGI, R., 1993, Estratégias alimentares utilizadas por cinco espécies de peixes comedoras de fundo do alto rio Paranál $P R$-MS. Dissertação de Mestrado, Universidade Federal de São Carlos, São Carlos, 142p.

GERKING, S. D., 1994, Feeding ecology of fish. Academic Press, San Diego, 416p.

GODINHO. A. L., 1993, E os peixes de Minas em 2010? Ciência Hoje, 16(91): 44-49.

GOMES, L. C. \& AGOSTINHO, A. A., 1997, Influence of the flooding regime on the nutritional state and juvenile recruitment of the curimba, Prochilodus scrofa, Steindachner, in upper Paraná River, Brazil. Fisheries Management and Ecology, 4: 263-274.

GOULDING, M., 1980, The fishes and the forest. Explorations in Amazonian Natural History. University of California Press, Berkeley, 279p.

HYSLOP, E. J., 1980, Stomach contents analysis - a review of methods and their application. J. Fish Biol., 17: 411-429.
KAWAKAMI, E. \& VAZZOLER, G., 1980, Método gráfico e estimativa de índice alimentar aplicado no estudo de alimentação de peixes. Bolm. Inst. Oceanogr., São Paulo, 29(2): 205-207.

LOWE-McCONNELL, R. H., 1984, The status of studies on Southern America freshwater food fish. In: T. M. Zaret (ed.), Evolutionary Ecology of Neotropical freshwater fishes. Dr. W. Junk, The Netherlands, 173p.

LUIZ, E. A., AGOSTINHO, A. A., GOMES, L. C. \& HAHN, N. S., 1998, Ecologia trófica de peixes em dois riachos da bacia do rio Paraná. Rev. Brasil. Biol., 28(2): 273-285.

MESCHIATTI, A. J., 1995, Alimentação da comunidade de peixes de uma lagoa marginal do Rio Mogi-Guaçu, SP. Acta Limnologica Brasiliensia, 7: 115-137.

MIRANDA, M. O. T., RIBEIRO, L. P., ARANTES, F. S., SIQUEIRA, A. M. \& DINIZ, M. G., 1988, Diagnóstico do setor pesqueiro no estado de Minas Gerais. Superintendência do Desenvolvimento da Pesca - SUDEPE (Relatório), Belo Horizonte, 30p.

POMPEU, P. S., 1997, Efeitos das estações seca e de cheia e da ausência de cheias nas comunidades de peixes de três lagoas marginais do médio São Francisco. Dissertação de Mestrado, Universidade Federal de Minas Gerais, Belo Horizonte, 72p.

RESENDE, E. K., CATELLA, A. C., NASCIMENTO, F. L., PALMEIRA, S. S., PEREIRA, R. A. C., LIMA, M. L. \& ALMEIDA, V. L. L., 1995, Biologia do curimbatá (Prochilodus lineatus), pintado (Pseudoplatystoma coruscans) e cachara (Pseudoplatystoma fasciatum) na bacia hidrográfica do rio Miranda, Pantanal do Mato Grosso do Sul, Brasil. EMBRAPA, Corumbá, 75p.

RESENDE, E. K., PEREIRA, R. A. C., ALMEIDA, V. L. L. \& SILVA, A. G., 1996, Alimentação de peixes carnívoros da planície inundável do rio Miranda, Pantanal, Mato Grosso do Sul, Brasil. EMBRAPA, Corumbá, 36p.

RIBEIRO, L. P. \& MIRANDA, M. O. T., 1990, Localização de juvenis de surubim (Pseudoplatystoma coruscans) em lagoas marginais do rio São Francisco - Município de Januárial $M G$. Superintendência do Desenvolvimento da Pesca SUDEPE (Relatório), Belo Horizonte, 29p.

SATO, Y., CARDOSO, E. L. \& AMORIM, J. C. C., 1987, Peixes das lagoas marginais do rio São Francisco a montante da represa de Três Marias (Minas Gerais). CODEVASF, Brasília, $42 \mathrm{p}$.

TUNDISI, J. G., 1986, Ambiente, represas e barragens. Ciência Hoje, 5(27): 48-54.

UIEDA, V. S., BUZZATO, P. \& KIKUCHI, R. M., 1997, Partilha de recursos alimentares em peixes em um riacho de serra do sudeste do Brasil. An. Acad. Bras. Ci., 69(2): 243-252.

VANNOTE, R. L., MINSHALL, G. W., CUMMINS, K. W., SEDELL, J. R. \& CUSHING, C. E., 1980, The River Continuum Concept. Can. J. Fish. Aquat. Sci., 37: 130137.

ZAVALA-CAMIN, L. A., 1996, Introdução aos estudos sobre alimentação natural em peixes. EDUEM, Maringá, 129p. 